\title{
KARAKTER KEILMUAN ISLAM DI PESISIR UTARA DAN PEDALAMAN JAWA TENGAH, NUSANTARA ABAD KE 15-17 ${ }^{1}$
}

\author{
Ismawati \\ IAIN Walisongo Semarang \\ ismawati@yahoo.com
}

\begin{abstract}
Awal penyebaran keilmuan Islam di pesisir utara dan pedalaman Jawa Tengah memiliki rentang waktu berbeda. Di pesisir utara masyarakat menerima penyebaran lebih dahulu dibanding daerah pedalaman. Hal ini mengakibatkan perbedaan tingkat pemahaman di antara dua entitas masyarakat tersebut. Pengajaran agama di pesisir utara didahului dengan pengajaran membaca al-Qur'an sebagai elemen penting dalam praktik keagamaan, dilanjutkan membaca dan menulis huruf Arab di rumah-rumah atau di mushalla. Anak-anak muda melanjutkan belajar pengetahuan yang tingkatnya lebih tinggi, berupa naskah klasik berbahasa Arab dan tarekat Syattariyah. Karakter keilmuan Islam di pesisir utara Jawa Tengah memperlihatkan corak legalistik dan menjaga dari aspek mistisisme yang menyesatkan. Sementara di daerah pedalaman Jawa Tengah pengajaran keilmuan Islam menekankan aspek tarekat yang bercorak heterodoks. Keilmuan ini bermula dari ajaran Syaikh Siti Jenar dan pengaruh Hindu yang lama berakar pada masyarakat Jawa, sehingga keilmuan Islam berkarakter kurang memperhatikan aspek legalistik.
\end{abstract}

Kata kunci: keilmuan Islam, pesisir utara Jawa Tengah,pedalaman

\section{PENDAHULUAN}

Agama Islam menunjukkan keberhasilan dakwahnya secara berangsur-angsur di daerah pesisir utara Jawa Tengah pada abad 15 . Perkembangan penduduk yang memeluk agama Islam di wilayah pesisir

TEOLOGIA, VOLUME 23, NOMOR 1, JANUARI 2012 
utara Jawa terus meningkat, sehingga para penyebar Islam dan ulama yang mengajarkan keilmuan Islam di rumah-rumah menganggap sudah waktunya membangun masjid sebagai sarana penyebaran keilmuan Islam yang lebih efektif. Ulama dalam masyarakat muslim adalah orang yang dianggap memiliki keluasan dan kedalaman ilmu-ilmu agama, tempat orang bertanya dan meminta fatwa, memiliki rasa khasysyah "takut dan cinta" yang tinggi kepada Allah, senantiasa memelihara hubungan dengan Nya (QS al-Fatir 28). Masjid yang dibangun di wilayah pesisir utara Jawa tampaknya telah mendahului masjid-masjid yang dibangun di wilayah pedalaman Jawa. Di beberapa masjid itu warga masyarakat memperoleh pengajaran keilmuan Islam dari para ulama Pada umumnya para ulama pada masa itu tidak memisahkan hal-hal yang berkaitan antara kehidupan yang bersifat duniawi dan rohani, sesuai dengan ajaran agama Islam itu sendiri. ${ }^{2}$ Mereka memberikan penyuluhan agama Islam yang sesuai dengan kondisi intelektual masyarakat pesisir utara Jawa abad ke 15-17 yang lebih cenderung kepada mistisisme dibanding dengan pemahamannya kepada fiqh. Di samping itu mereka juga memberikan contoh bagaimana cara bercocok tanam, mengerjakan kerajinan dan perdagangan kepada masyarakat di sekitarnya. ${ }^{3}$ Karena target pemerintahan pusat Islam di Demak adalah menjadikan wilayah kesultanan menjadi kuat sebagai wilayah berbasis agraris yang mantap dengan dukungan pengembangan maritim. Para ulama ikut mensukseskan program penguatan pemerintahan Sultan Fatah dengan menjadikan sebagai wilayah agraris dan maritim, bahkan mereka juga memberdayakan masyarakat pada bidang sosial, politik, ekonomi dan budaya. ${ }^{4}$

\section{KONDISI SOSIAL PESISIR UTARA JAWA PADA MASA AWAL KEDATANGAN ISLAM}

Pada pertengahan abad ke-13 agama Islam diperkenalkan langsung oleh para pedagang Gujarat dan Persia ke Jawa. Mereka berdatangan dan menetap di sepanjang pesisir utara Jawa, membaur dan menikah dengan wanita pribumi, sehingga terbentuk keluarga baru muslim. Peranan kota pesisir dan bandar niaga seperti Tuban, Gresik, dan Surabaya sangat besar. Meningkatnya kehadiran pedagang muslim di pesisir utara merambah ke Mojokerto dekat dengan ibukota Majapahit yang Hindu Budha. Banyaknya batu nisan di Troloyo Mojokerto bertahun 1376, 1380, 1407, 1418, 1427, 1467, 1469 dan $1475 \mathrm{M}^{5}$ menunjukkan bahwa paling tidak sejak pertengahan abad ke-14 penyebaran Islam telah memperoleh pijakan kukuh di pesisir utara Jawa. ${ }^{6}$ Awal abad ke-15 Majapahit mengalami kemunduran 
dan hal ini menguntungkan transmisi Islam. ${ }^{7}$ Walaupun demikian rajanya, Wikramawardana masih menolak ajakan ulama Malik Ibrahim untuk memeluk Islam. Sementara itu para pedagang Tionghoa ikut pula memainkan peran besar dalam membangun peradaban modern saat mendirikan Gresik, Jepara pada akhir abad ke-14 dan awal abad ke-15. ${ }^{8}$

Demikian pula di Tuban (jumlah penduduk 1.000 kepala keluarga), Mojokerto (jumlah penduduk 200-300 kepala keluarga) dan Surabaya (jumlah penduduk 1.000 kepala keluarga) telah menetap para perantau Tionghoa muslim dari Zhengzhou, Quanzhou dan Propinsi Guangdong yang hidup berdagang dan menjadi lurah seperti di Gresik. Armada dagang Tionghoa pimpinan Laksamana muslim Ceng Ho yang berlayar 7 kali mulai 1405-1433 singgah pula di bandar niaga utara Jawa tersebut sebanyak 6 kali termasuk di Semarang ${ }^{9}$

Pelayaran pertama armada tersebut sampai ke pesisir utara Jawa Timur saat terjadi perang saudara Majapahit ke-2 pada tahun 1404-1406. Karena kesalahpahaman armada Ceng Ho diserang oleh Wikramawardana menyebabkan 170 awak kapal Ceng Ho tewas akibat disangka bersekutu dengan Bhre Wirabumi Blambangan. Namun hal ini diangap selesai karena telah dilakukan permintaan maaf dan pembayaran ganti rugi kepada Raja Ming sebesar 10.000 tail emas.

Armada dagang Ceng Ho mengimpor hasil bumi Indonesia antara lain minyak tanah, kapuk, belerang, cengkeh merica dan kapulaga, kemenyan hitam, kemenyan Arab, kemenyan hantu, kemenyan serani, kayu gaharu, sarang burung layang-layang, binatang langka, ratna mutu manikam yang berharga. Sedangkan orang Jawa menyukai barang-barang dari Tiongkok berupa porselein berbunga biru, jebat, kain sutera berbenang emas, vermilyun dan sebagainya yang dibayar dengan uang kepengan Tiongkok sebagaimana ditulis Ma Huan dalam bukunya Ying Ya Sheng Lan (Pemandangan Indah di Seberang Samudera).

Adat istiadat penduduk Jawa pada abad itu sederhana, kaum prianya rambutnya terurai sedangkan kaum wanitanya berkonde, sementara di Surabaya baik pria maupun wanita berkonde semua. Mereka memakai baju panjang dan pinggangnya dililit dengan kain berlipat. Kaum pria baik tua atau muda, kaya atau miskin semua memiliki keris. Rakyat kecil tinggal di pondok yang terbuat dari kajang atau ilalang. Dalam pondok terdapat suatu gudang yang terbuat dari batu bata, tempat menyimpan barang, di mana orang duduk bersila tanpa bangku atau tidur di atasnya tanpa ranjang. Mereka suka mengunyah sirih dengan pinang, kapur dan pelengkap lainnya sepanjang hari dan sebagai suguhan tamu. Sebelum makan mulutnya dicuci 
dahulu dengan air agar bersih dari ampas sirih. Kedua tangannya dibersihkan pula, dan mereka duduk bersila secara berkerumun dan makan dari piring yang penuh nasi bercampur sayur dengan jari tanpa sumpit atau sendok. Bila haus mereka langsung minum tanpa gelas. Sedangkan Raja Majapahit di Mojokerto tinggal dalam bangunan bertembok bata yang tingginya sekitar 9,3 m dan luasnya 200 kaki. Dalam bangunan istana terpasang papan yang atasnya terbentang tikar rotan tempat orang bersila. Genting istana terbuat dari papan kayu yang bercelah. Sang Raja memakai mahkota yang berhias kembang emas dan memakai kain yang dijelujur dengan benang sutera dan berkeris. Sebagaimana rakyatnya raja tak pernah memakai alas kaki dan biasanya naik gajah atau cikar bila bepergian ke tempat yang agak jauh ${ }^{10}$

Adapun adat perkawinan Jawa pengantin laki-laki datang dulu ke rumah keluarga pengantin perempuan. Kemudian setelah 3 hari menikah, pengantin perempuan akan dijemput ke rumah keluarga pengantin laki-laki. Dalam penjemputan ada pula orang-orang yang mengenakan keris. Pengantin perempuan berkain tetapi tidak mengenakan alas kaki. Ia dihiasi selendang yang bersulam sutera serta kalung dan gelang emas dan perak. Pengantin perempuan dijemput dengan sebuah perahu yang dihiasi dengan daun-daun sirih dan pinang sebagai tanda selamat datang. Setelah tiba dibunyikanlah berbagai alat musik seperti genderang, canang dan tempurung kelapa dengan ramainya. Selanjutnya pesta dimulai sampai beberapa hari. Sedangkan penguburan jenazah tergantung dari pesan yang akan meninggal apakah diperabukan atau dilepaskan ke dalam air. Bagi yang kaya atau tokoh masyarakat, isteri dan beberapa pembantu perempuan dua atau tiga terdekat rela diperabukan bersama tuannya.

Di Majapahit terdapat pula adat pertarungan bambu runcing di lapangan. Dua barisan berhadap-hadapan, dikepalai seorang laki-laki memegang bambu runcing dan diiringi oleh isteri yang bersenjatakan tongkat sepanjang 1 meter dan para pelayannya. Laki-laki bersenjata bambu runcing itu bertarung 3 kali dalam iringan bunyi genderang. Bila isteri berteriak: Larak, larak, (mundur, mundur Jw) maka selesailah pertarungan itu. Raja yang menonton bersama permaisuri dalam kereta berkuda memerintahkan yang menang untuk memberi uang pada keluarga yang kalah dan mati. Namun sebagai balasannya isteri si korban dibawa oleh lakilaki yang menang dalam pertarungan bambu runcing itu. ${ }^{11}$

Masyarakat pesisir utara Jawa pada masa itu terdiri dari beberapa komunitas yang mudah dikenali karena berbeda. Komunitas muslim asing Arab dan Persia yang umumnya pedagang, dikenali dengan pakaian dan 
makanan yang bersih dan bagus, komunitas Tionghoa yang sebagian besar muslim, melakukan puasa dan shalat dikenali pula dari pakaiannya yang bersih dan makanan terpilih, sementara orang pribumi Jawa jorok, berkaki telanjang dan masih animistic. ${ }^{12}$ Peradaban Islam yang diperkenalkan oleh muslim asing Arab, Persia dan Tionghoa rupanya mempengaruhi masyarakat pesisir utara Jawa di Tuban, Gresik, Surabaya, Demak dan Semarang terlebih dahulu dibanding kepada masyarakat pedalaman.

\section{PENGAJARAN KEILMUAN ISLAM AWAL DI PESISIR UTARA JAWA NUSANTARA}

Gambaran di atas menunjukkan bahwa masyarakat Jawa awal abad ke-15 masih memeluk kepercayaan animistik-dinamistik dan Hindu Budha. Sementara ajaran Islam telah disebarkan oleh pedagang muslim asing dari berbagai negeri terutama dari Arab, karena mereka dipandang lebih menguasai keilmuan Islam. ${ }^{13}$

Penyebaran keilmuan Islam memunculkan pengajaran keilmuan Islam di rumah ketika masyarakat Islam pesisir utara Jawa menginginkan pengajaran terlaksana dengan segera atau di langgar sebagai pusatnya. Pengajaran agama didahului dengan pengajaran membaca al-Qur'an dari kiai kepada santrinya ${ }^{14}$ yang merupakan elemen penting dalam praktik keagamaan. ${ }^{15}$ Pengajaran tingkat dasar ini dilengkapi dengan membaca dan menulis huruf Arab. ${ }^{16}$ Penyebaran agama di rumah sebelumnya merupakan tradisi masyarakat Islam Arab di masa Rasulullah. Sementara langgar merupakan sarana pengajaran yang hampir sama dengan masjid, namun dalam bangunan lebih kecil. Langgar juga dipergunakan sebagai tempat shalat dan belajar mengaji al-Qur'an untuk anak-anak, menyebarkan keilmuan agama dan melaksanakan musyawarah. Peningkatan jumlah santri dari luar daerah, memerlukan tambahan bangunan di sekitar langgar untuk pemondokan mereka. Penambahan ini menuntut bangunan masjid sebagai tempat melaksanakan shalat Jum'at dan proses pengajaran agama dalam naskah klasik berbahasa Arab, ${ }^{17}$ yang merupakan embrio munculnya pesantren. Pesantren menjadi tempat anak-anak muda belajar pengetahuan keagamaan yang tingkatnya lebih tinggi, yaitu naskah-naskah klasik berbahasa Arab.

Sebelum munculnya istilah pesantren orang Jawa telah mengenal istilah padepokan tempat pengajaran agama Hindu Budha. Dengan munculnya pesantren ${ }^{18}$ muslim pesisir utara Jawa dapat meningkatkan pendidikan anak-anaknya setelah tingkat dasar di rumah, langgar atau mushalla dan masjid. 
Kehadiran Malik Ibrahim di Gresik pada akhir abad ke14, Sunan Ampel pada awal abad ke-15, serta ulama dan pedagang asing dari Gujarat, Persia dan Arab atau bahkan dari Pasai telah mengajarkan kitab-kitab keilmuan Islam dari Timur Tengah saat penyebaran Islam awal di pesisir utara Jawa. ${ }^{19}$ Keberadaan mereka di Jawa memunculkan pesantren sebagai penerusan lembaga madrasah di Makkah dan Madinah. Asumsi tersebut sangat mungkin karena struktur pesantren di Jawa sangat terkait dengan struktur madrasah Timur Tengah, mengambil model madrasah di Nishapur yang telah melembaga sejak abad ke-9 $\mathrm{M}^{20}$

Munculnya pesantren oleh Malik Ibrahim di Gresik, ${ }^{21}$ pesantren Ampel oleh Sunan Ampel ${ }^{22}$ dan pesantren Giri oleh Sunan Giri ${ }^{23}$ tidak terlepas dari kegiatan tarekat ${ }^{24}$ oleh penyebar Arab, Persia dan Gujarat. Tarekat diperkirakan muncul sebagai akibat runtuhnya kesatuan politik umat Islam dengan jatuhnya kekhalifahan Baghdad tahun 1258, dan tarekat telah mulai aktif di pesisir utara Jawa sejak abad ke-15. ${ }^{25}$ Pesantren awal menyediakan ruangan untuk mengamalkan tarekat, penginapan, dapur memasak di sekitar kiri kanan masjid. Lembaga pesantren yang memberikan pendidikan keilmuan agama bagi anak-anak tidak dipisahkan dengan pusat kegiatan tarekat. ${ }^{26}$ Keduanya saling menunjang dan menguatkan, merupakan kesatuan penyebaran keagamaan pada masa awal kehadiran Islam di pesisir utara Jawa. ${ }^{27}$ Hal itu dibuktikan pula penyebaran tarekat Syattariyah sebagai tarekat tertua di pesantren pesisir utara Jawa abad ke$15{ }^{28} \mathrm{Ki}$ Ageng Pandan Arang Semarang, Sunan Katong Kaliwungu dan Wali Gembyang Kendal atau Syaikh Syattariyah awal abad ke-16 juga mengajarkan tarekat dalam transmisi keilmuannya. Pendapat ini menolak anggapan Drewes yang menyebut bahwa tarekat Syattariyah mulai dikenal di Jawa pada pertengahan abad ke-17. ${ }^{29}$

Lembaga pendidikan Islam menindaklanjuti dengan pengajaran keilmuan yang bersumber dari al-Qur'an, Hadis dan ilmu keislaman, seperti ushul, fiqh, dan tasawuf yang ditulis oleh para ulama salaf dalam kitab-kitab klasik. ${ }^{30}$ Jenis keilmuan yang diajarkan para ulama menunjukkan bahwa semenjak abad ke-15 keilmuan Islam yang bercorak ortodoks legalistik atau fiqh $^{31}$ dan tasawuf telah diajarkan dan diamalkan secara bersama-sama oleh masyarakat pesisir utara Jawa. ${ }^{32}$

Kitab klasik itu ditemukan pelaut Belanda pimpinan Cornelis de Houtman di bandar Gresik tahun 1596, karya ulama Nusantara berbahasa Melayu, Jawa dan Arab, yang kini disimpan di museum Universitas Amsterdam. Naskah berbahasa Arab dengan terjemahan Jawa ditulis disela baris tulisan Arab itu adalah al-Taqrib fi al-Fiqh karangan Abu Syuja' al- 
Isfahani, al-Idhah fi al-Figh anonim dan kitab terjemahan Qasidah Burdah al-Bushairi serta kitab Islam Jawi, kitab tasawuf Wejangan Seh Bari yang dipengaruhi Ihya' Ulum al-Din karya al-Ghazali dan Tamhid fi Bayan alTauhid karya Abu Syukur al-Kasyi al-Salimi, yang disandarkan pada Malik Ibrahim Gresik (w. 1419). ${ }^{33}$

Masyarakat awam pesisir utara Jawa juga menerima keilmuan Islam tentang akhlak dengan bahasa yang sederhana dari Sunan Ampel sekitar abad ke-15 sebagai berikut:

1. Moh Main, artinya tidak mau dan jangan melakukan main judi

2. Moh Minum, artinya tidak mau dan jangan melakukan minum minuman keras

3. Moh Maling, artinya tidak mau dan jangan melakukan pencurian

4. Moh Madat, artinya tidak mau dan jangan mengisap candu atau ganja

5. Moh Madon, artinya tidak mau dan jangan melakukan zina

6. Keilmuan Islam juga dituliskan dalam kitab klasik Wejangan Seh Bari, kitab tasawuf beraksara dan berbahasa Jawa yang dipelajari masyarakat muslim di pesisir utara Jawa masa itu. Kitab itu diperkirakan merupakan karya ulama setempat yang menyandarkan pada Sunan Bonang anak Sunan Ampel. Kitab itu menerangkan tentang tasawuf yang dipengaruhi oleh Al-Ghazali dalam kitabnya Ihya Ulum al-Din sebagai ulama tasawuf fase ke-3 yang mampu mengkompromikan al-tasawwuf al-akhlaqi dengan syari'at, seiring dengan aliran Ahl al-Sunnah wa al-Jama'ah. Isi kitab tasawuf klasik Wejangan Seh Bari antara lain diuraikan sebagai berikut:

43. Kaya ngapa mangripat tigang perkara?

Jawabe: kaping siji mangripatu dat, kaping kalih mangripatu sipat, lan kaping telu mangripatu apangal

44. Kaya apa tegese sawiji-wiji?

Jawabe: mangripatu dat: kaweruhana satuhune kahananing Pangeran lan sasipatira sadaya mahasuci, tanpa estu jisim, tanpa arah-arah, tan misra, tan awor, tan anuksma, tan sinuksma, rehing langgeng ananira mahasuci.

Anapon mangripatu sipat: kaweruhana sira, Pangeran urip langgeng nora kelawan ngawa angawikani tan kalawan budi, kawasa tan kalawan anggauta, aningali tan kalawan aksi, amiarsa tan kalawan karna, akarsa tan kalawan angen-angen, angandika tan kalawan lathi swara, kekel langgeng sipatira mahasuci, tan kadi aweting dumadi kabeh. 
Anapon mangripatu apangal: kaweruhana pakaryaning Pangeran tan kalawan parbot, asung tan kalawan tangan, amateni tan kalawan raga, iku tegesing mangripat tigang perkara ika. ${ }^{34}$

\section{Terjemahnya:}

43. Bagaimana makna makrifat tiga perkara?

Jawabannya: perta makrifat dzat, kedua makrifat sifat, dan ketiga makrifat af'al

\section{Bagaimana arti keesaan?}

Jawabannya: makrifat dzat: ketahuilah sebenarnya keadaan Allah dan semua sifatnya mahasuci, tanpa jisim yang tampak, tiada bersekutu, tiada berjiwa, tiada diberi jiwa, abadi keberadaanya Mahasuci.

Adapun makrifat sifat: ketahuilah olehmu, bahwa Allah hidup abadi tiada belajar pengetahuan untuk menebarkan pengetahuan dan tiada harus berusaha, berkuasa tanpa berupaya, melihat tanpa harus bermata, mendengar tanpa harus bertelinga, berkehendak tanpa harus beranganangan, bersabda tanpa harus berbibir bersuara, kekal abadi sifatnya Mahasuci, tiada sama dengan makhluk semuanya.

Adapun makrifat af'al: ketahuilah karya Allah tiada memerlukan peralatan, memberi tiada memerlukan tangan, membunuh tanpa raga, itulah arti ketiga makrifat itu.

Demikian pula Sunan Bonang ikut memberikan pesan keagamaan dengan bahasa sederhana sehingga masyarakat awam dengan mudah mampu mencerna. Pesan itu diuraikan sebagai berikut:

1. Wenehana teken marang wong kang wuta, artinya: Berilah tongkat kepada orang yang buta, maksudnya adalah: Berilah ilmu kepada orang yang bodoh

2. Wenehana mangan marang wong kang luwe artinya: Berilah makan kepada orang yang lapar, maksudnya adalah: Sejahterakanlah orang yang masih miskin

3. Wenehana busana marang wong kang wuda, artinya: Berilah pakaian kepada orang yang telanjang, maksudnya adalah: Ajarkanlah budi pekerti kepada orang yang tidak tahu malu atau atau belum berbudaya

4. Wenehana ngeyub wong kang kudanan, artinya: Berikanlah tempat berteduh kepada orang yang kehujanan, maksudnya 
adalah: Berilah perlindungan kepada orang yang sedang menderita $^{35}$

Kitab lainnya adalah An Early Javanese Code of Muslim Ethics, aslinya sudah dikenal di Jawa sejak abad ke- $15^{36}$ dan tersebar pula di Pajang pada abad ke-16. ${ }^{37}$ Dipastikan penulisnya mengenal kitab kuning berbahasa Arab, keilmuannya berhubungan dengan tradisi Timur Tengah dan mengungkapkan isinya ke bahasa Jawa dengan uraian sederhana yang sesuai dengan kondisi intelektual masyarakat masa itu. Isi kitab ini dijelaskan antara lain sebagai berikut:

Kadiyata wong kapir anganggo anggota den alema ta panganggone, atawa ana wong sasangi kang ana brahalane den sengguha ta mandi, kupur, ana wong duk ewah wus dadi Islam ta nora aweweh, atawa ana wong angucap ki Anu ika cekape angur kapir, kupur kang angucap iku, yen ana angucap mengkene atawa angucaping cangkeme ing atine belaka, uwus kapir, ana angucap endi becik agama selam lawan agama Jawa? Kupur.

\section{Terjemahnya:}

Sebagaimana kafir juga kalau ada orang kafir yang memakai pakaian dan orang memuji pakaiannya, atau ada orang yang berjanji atas nama berhala yang dianggap mujarab, maka termasuk kufur. Ada orang yang dahulunya telah berubah dan menjadi Islam tetapi tiada mau bersedekah (memberi), atau ada orang yang berucap, bahwa ki Anu hidupnya berkecukupan ketika masih kafir, maka kufurlah orang yang mengucapkan itu. Bila ada yang berucap begini atau yang berucap hanya mulutnya dan berbeda dengan hatinya, sudah kafirlah orang itu. Bila ada yang berkata mana yang lebih baik agama Islam dengan agama Jawa? Kufurlah orang itu.

Kitab lain yang tak kalah menariknya adalah kitab yang cukup lama dipelajari di kalangan pesantren yaitu kitab Musawaratan, ditulis berhuruf Jawa dan ada yang berhuruf Arab berbahasa Jawa, memperlihatkan corak legalistik dan mempertahankan dari unsur mistik yang menyesatkan. ${ }^{35} \mathrm{Kitab}$ Musawaratan antara lain menguraikan sebagai berikut:

1. Sakatahing para wali, samya paguneman rahsa, ing Giri Gajah anggone, akarsa musawaratan, ing bab masalah tekad, den waspada ing Hyang Agung, wajib sami nyatakena

2. Ing malem Jumungah pasti, tanggal ping lima ing wulan, Ramelan nuju sasine, anenggih alip tahunya, kangjeng Pangeran Bonang, ingkang miwiti karuhun, lan Pangeran Kalijaga 
3. Seh Bentong Molana Maghrib, nenggih kalih Seh Lemahbang, lan pangeran Majagung, pangeran Cirebon lawan, Pangeran Giri Gajah, samya agunem ing ngelmu, jenenging masalah tekad

4. Jeng pangeran Ratu Giri, amiwiti angendika, eh anak manira kabeh, pratingkahing wong makripat, aja dadi parbutan, dipun sami ngelmunipun, pada eling pinelingan

5. Wong wowolu dadi siji, aja ana wong kumalamar, dipun rujuk ing karepe, den waspada ing pangeran, kangjeng pangeran Bonang, ingkang miwiti karuhun, amedar ing pangawikan

6. Ing karsa manira iki, iman tokid lan makripat, suwung ilang paningale, tan na kang katingalan, ilang jenenging tingal, nunten pangeran kang agung, kang anembah kang sinembah ${ }^{36}$

\section{Terjemahnya:}

1. Sejumlah para wali, pada membahas masalah rahasia, di Giri Gajah tempatnya. Mereka akan bermusyawarah tentang masalah I'tiqad, agar waspada terhadap Allah, mereka berkewajiban untuk berkomitmen.

2. Pada malam Jum'at yang jelas, tanggal lima di bulan Ramadhan, bertepatan tahun Alip, Kangjeng Pangeran Bonang memulai pembicaraan bersama dengan Pangeran Kalijaga

3. Syaikh Bentong Maulana Maghrib, bersama dengan Syaikh Lemah Abang, dan Pangeran Majagung, Pangeran Cirebon dan Pangeran Giri Gajah, pada membahas pengetahuan yang disebut masalah I'tiqad.

4. Kanjeng Pangeran Ratu Giri, memulai berbicara, wahai ananda semuanya, sikap dalam makrifat, janganlah pada berebut, disamakan ilmunya dan hendaknya saling mengingatkan

5. Delapan orang ini hendaknya menjadi satu, janganlah saling berselisih, hendaknya saling menyetujui, dan waspada kepada Pangeran Kanjeng Sunan Bonang yang memulai menguraikan pengetahuan tentang Tuhan.

6. Dalam kehendakmu itu, keimanan dan tauhid serta ilmu tarekat, kosong hilang pengkihatannya, hilanglah namanya penglihatan, selanjutnya Allah Yang Maha Agung, tiada yang nampak kecuali yang menyembah dan yang disembah

Kitab lain yang muncul pada abad ke-16 adalah kitab Salokantara berbahasa Jawa, yang dinisbatkan kepada Sultan Fatah dari Demak. ${ }^{37}$ Kitab- 
kitab itu adalah produk intelektual muslim Jawa pada masanya, dipelajari masyarakat pesisir dan merupakan gambaran kondisi intelektual masyarakat pesisir utara Jawa abad ke 15-17.

Sekitar abad ke-16, keilmuan Islam berpengaruh kuat di pusat-pusat Islam di sepanjang pesisir utara Jawa. Pengajaran ini menyebar pula di Pajang, daerah pedalaman Jawa Tengah, terutama masa pemerintahan Hadiwijaya. Kitab klasik berbahasa Arab yang diajarkan adalah Safinah alNajah, Durrah al-Nasihin serta untuk sebagian kelompok santri tertentu diajarkan kitab Ihya 'Ulum al-Din. Bahkan di daerah Pengging, wilayah pedalaman Jawa Tengah kitab sharaf Kailani telah diajarkan oleh Syaikh Siti Jenar. ${ }^{38}$ Sementara itu doktrin mistik heterodoks berkembang pula ${ }^{39}$ yang berpusat di pedalaman, sehingga memunculkan perdebatan antara pendakwah doktrin misti ortodoks dan pendakwah heterodoks yang berakhir dengan kemenangan doktrin mistik ortodoks.

Akibat pengajaran yang bercorak ortodoks legalistik atau fiqh dan doktrin mistik ortodoks, maka pada sekitar abad ke-17 karya mistik heterodoks hampir tidak muncul lagi dalam sastra keagamaan di wilayah pesisir utara Jawa Tengah. ${ }^{40}$

Para ulama menyampaikan ajaran Islam agar masyarakat great tradition bisa melaksanakan secara taat pada masa awal. Namun para ulama cukup toleran terhadap masyarakat little tradition dengan mengajarkan bentuk luar kepercayaan yang masih bercampur dengan kepercayaan dan kebiasaan lokal. Masyarakat little tradition diusahakan sedapat mungkin mampu menjalankan praktik agama secara benar. Mereka tetap menempatkan ajaran Islam dalam bentuk konsep asli dan tidak diolah dalam bentuk fusi atau sinkretisasi. Para pengajar membiarkan sementara kepercayaan teosentris Islam diterima lebih dahulu, tanpa menghilangkan kepercayaan lama. Dalam taraf ini ada dualisme kepercayaan, Islam dan Islam dengan kepercayaan lokal yang seiring, tapi bukan sintesa. Karena kepercayaan Islam tidak memungkinkan terjadinya sintesa dengan kepercayaan lokal. ${ }^{41}$

\section{KARAKTER KEILMUAN ISLAM DI PESISIR UTARA JAWA TENGAH ABAD KE-17}

Masa ini merupakan masa peralihan dari pengaruh kuat tarekat heterodoks kepada tarekat ortodoks. Penyebaran keilmuan agama pada awal abad ke-15 yang banyak dilakukan oleh penyebar Arab dilanjutkan oleh pemuda Melayu-Nusantara yang menimba ilmu langsung dari Makkah dan

TEOLOGIA, VOLUME 23, NOMOR 1, JANUARI 2012 
Madinah. Hubungan antara kerajaan-kerajaan Islam Nusantara dan Timur Tengah di bidang ekonomi, diplomatik dan keagamaan ini semakin ekstensif sebelum abad ke-17. Hal ini memungkinkan bagi orang Nusantara melaksanakan haji dan sekaligus menuntut ilmu ke Makkah. ${ }^{42}$

Partisipasi para pemuda Melayu-Nusantara dalam mengembangkan intelektualisme dan spiritualisme keislaman di Makkah dan Madinah, terbangun dalam jaringan ulama terkemuka Hijaz, yaitu Ahmad al-Qushashi dan Ibrahim ibn Hasan al-Kurani al-Kurdi (wafat $1101 \mathrm{H}$ ). Penyebaran oleh ulama Nusantara yang terlibat dalam jaringan intelektual Makkah, sejak Abd al-Rauf al-Singkili (1620-1695 M) disusul Yusuf al-Makassari (16261699 M) berhasil mereduksi karakter praktik keagamaan heterodoks dan pra-Islam yang dilakukan sebagian masyarakat. Sementara di Jawa tidak muncul ulama sekelas Abd al-Rauf al-Singkili dan Yusuf al-Makassari karena kebijakan monopoli ekspor pemerintahan kerajaan Islam di Mataram. Amangkurat I menutup bandar niaga di pesisir utara Jawa (1652 $M)^{43}$ dan akibat perseteruan dengan para ulama menyebabkan pemuda Jawa tidak mampu lagi berkomunikasi dengan teman di seberang pulau apalagi untuk belajar ke Makkah. ${ }^{44}$

Abd al-Rauf al-Singkili meminta gurunya, Ibrahim ibn Hasan alKurani menyusun kitab Tuhfat al-Mursalah (1660 M) untuk mengoreksi tulisan tasawuf heterodoks Tasawuf Wahdat al-Wujud dari Muhammad ibn Fadlullah al-Burhanpuri India yang berkembang di Nusantara. Putra ulama Ibrahim ibn Hasan al-Kurani di Madinah, Muhammad Abu Thahir adalah guru dari beberapa orang Indonesia, menggantikan ayahnya sebagai syaikh tarekat Naqsyabandiyah dan Qadiriyah. ${ }^{45}$ Di Madinah, tugas Muhammad dilanjutkan oleh kawannya Muhammad ibn Abd Rasul al-Barzanji. Bacaan Tahlil, bentuk doa yang dihubungkan dengan Abd al-Qadir Jailani pendiri tarekat Qadiriyah telah disebar luaskan oleh para murid Muhammad Abu Thahir dan telah sampai di Jawa pada abad ke $17^{46}$

Bersama dengan bacaan dari kitab Al-Iqd al-Jawahir atau al-Barzanji tentang maulid Nabi susunan Ja'far ibn Hasan ibn Abd al-Karim ibn Muhammad al-Barzanji dan Lujain al-Dani fi Manaqib Abd al- Qadir Jailani tentang riwayat pendiri tarekat Qadiriyah semuanya merupakan bacaan baku bagi pengikut tarekat Qadiriyah yang tersebar ke pesisir utara Jawa, Banten dan Cirebon sejak abad ke-17. ${ }^{47}$

Praktik keagamaan di daerah pesisir utara Jawa Tengah terbukti memperoleh koreksi dari pusat keilmuan Makkah Madinah dengan memudarnya tasawuf heterodoks dan kepercayaan lokal yang bercirikan sinkretisme, ketertarikan terhadap hubungan kekuatan magis dan dunia 
gaib, ${ }^{48}$ serta berubah menjadi menitikberatkan pada sintesa baru yaitu keselarasan dengan tuntutan syari'at Islam pada abad ke-17.

\section{KARAKTER KEILMUAN ISLAM DI PEDALAMAN JAWA TENGAH ABAD KE-16 DAN KE-17}

Sekitar akhir abad ke-16 pusat kekuasaan Islam berpindah ke daerah pedalaman Jawa Tengah. Secara geografis wilayah pedalaman masih berupa hutan belantara atau tanah persawahan yang baru dibuka. Tingkat pemahaman keilmuan Islam masyarakat awam lebih rendah dibanding dengan masyarakat pesisir utara yang lebih dahulu mendapatkan pengajaran dari para pendakwah. Penyampaian keilmuan Islam di daerah pesisir utara yang dilakukan pedagang dinamis, di daerah pedalaman kini bersandar pada petani yang statis. Islam turun dari budaya kosmopolitan menjadi budaya local yang kehilangan karakter universalitasnya. ${ }^{49}$ Kondisi lingkungan dan pekerjaan masyarakat petani, mempengaruhi cara berfikir dari historis realistis menjadi bersifat mitos. Pada saat yang sama, pemahaman keilmuan Islam mereka masih diwarnai pemahaman keagamaan lama, yaitu Hindu Budha, sehingga melalui karakter keilmuan Islam demikian ini, menyulitkan masyarakat Jawa pedalaman Jawa Tengah menerima keilmuan Islam dalam waktu cepat. ${ }^{50}$ Artinya vitalitas keilmuan Islam dari pesisir utara meredup, karena karakter tradisi besar hanya sedikit saja jumlahnya pada golongan atas, sedangkan kelompok massa yang lebih besar jumlahnya berkarakter tradisi kecil ${ }^{51}$ Keilmuan Islam ditampilkan dalam bahasa Jawa yang lebih didominasi oleh aspek tasawuf yang berkarakter heterodoks. Keilmuan Islam pada masa ini dimunculkan dalam tulisan yang dikenal dengan serat suluk dan serat wirid. Kedua serat ini menampilkan ajaran tasawuf yang berkarakter sinkretisme, perpaduan Islam dan Hindu Budha. Selanjutnya keilmuan Islam tentang cerita atau kisah keislaman tentang Nabi misalnya, ditampilkan dalam Babad. Sementara primbon mempresentasikan rangkuman berbagai ajaran yang berkembang dalam tradisi Jawa, seperti ngelmu petung, ramalan, guna-guna, serta pilihan sebagian ajaran Islam ${ }^{52}$ yang kemudian dikenal dengan kitab kejawen. Pada abad sebelumnya, bibit keilmuan kejawen sudah tampak, karena Sultan Hadiwijaya (1550-1582 M) di Pajang, pedalaman Jawa Tengah masih tetap berpegang pada adat dan budaya pedalaman yang sinkretis. Di pedalaman Jawa Tengah yang pada abad pertiga akhir abad menjadi pusat kekuasaan, keilmuan Islam sinkretis, selanjutnya dikenal dengan ilmu kejawen semakin berkembang. Pengaruh masa Hindu yang telah berakar sekitar 1600 tahun menguntungkan kearah

TEOLOGIA, VOLUME 23, NOMOR 1, JANUARI 2012 
karakterik ini. Pada umumnya tulisan-tulisan keilmuan Islam berkarakter kejawen inilah yang beredar di masyarakat. Terlebih ketika kewibawaan Mataram meningkat dibawah Panembahan Senapati (1578-1601 M) mampu mengalahkan kewibawaan Sultan Hadiwijaya di Pajang. ${ }^{53}$ Di masa pemerintahan Sultan Agung politik Islamisasi dilakukan, dengan cara mempertemukan keilmuan Islam dengan tradisi Hindu Jawa yang telah ada di masyarakat pedalaman Jawa Tengah ${ }^{54}$ seperti tertulis dalam wirid, serat dan suluk serta primbon. Keilmuan Islam dengan karakter baru ini ditransmisikan dengan warna lain, bahkan bisa bertolak belakang dengan makna Islam yang sebenarnya. Keilmuan Islam itu mereka namakan juga Ilmu Haqiqat, Kenyataan Yang Tertinggi, kadang-kadang Ilmu Martabat Tujuh artinya ajaran tentang Tujuh Martabat Yang Ada, yang mencoba memberikan gambaran peredaran abadi penjelmaan-penjelmaan Yang Mutlak. Uraian-uraian pengetahuan dalam bentuk syair yang dinisbatkan kepada delapan atau sembilan orang wali Jawa, menjadi karakter khas dalam suluk. Serat Suluk Sukarsa, disebutkan berisikan ungkapan-ungkapan yang seiring dengan ajaran Hamzah al-Fansuri ${ }^{55}$ telah muncul mendahului kedua manuskrip Sunan Bonang, Primbon Jawa Abad ke-Enam Belas dan Pitutur Seh Bari. Masa pemerintahan Panembahan Seda ing Krapyak (1601-1613), muncul pula Serat Suluk Wujil, yang mempertemukan tradisi Jawa dengan Jawa dengan ajaran tasawuf Islam, yang menyebutkan pitutur Sunan Bonang kepada Wujil, seorang bujang mantan budak raja Majapahit. ${ }^{56}$ Syair serat ini biasa dinyanyikan pada malam hari di kalangan keluarga dan kawan-kawan sebagai pengisi waktu di malam hari. Dengan mempelajari suluk ini kegiatan peribadatan Islam yang menjadi kewajiban kurang diperhatikan ${ }^{57}$ Sampai dengan masa pemerintahan Mataram berpindah ke Kartasura (1680-1744), tradisi keilmuan Islam di Jawa pedalaman semakin diperkaya dengan lahirnya serat-serat Menak.dengan sekar Macapat. Keilmuan Islam ini mentransmisikan keilmuan Islam Melayu, semisal Hikayat Amir Hamzah. Sebenarnya induk awal dari serat Menak ini berasal dari Persia ${ }^{58}$ yang telah dikenal di Jawa semenjak abad ke-16. ${ }^{59}$ Sebagaimana pada abad ke-18 dan ke-19, keilmuan kejawen model tasawuf heterodoks itu muncul lagi, seperti: Serat Centini disusun oleh Yasadipura II, Ranggasutrasna, dan Raden Ngabehi Sastradipura. Serat Wirid Hidayat Jati disusun oleh Raden Ngabehi Ranggawarsita. Suluk Martabat Wahdat Wakidiyat yang ditulis oleh Pakubuwana III dan Serat Wedatama yang disusun oleh Mangkunegara IV ataupun Serat Wulangreh disusun oleh Pakubuwana IV. Ajaran Martabat Tujuh sebagai misal keilmuan Islam yang berkarakter pedalaman Jawa, menjelaskan tentang 
penciptaan manusia, selanjutnya menghasilkan adanya tujuh unsur penyusun diri manusia. Dalam ajaran Serat Wirid Hidayat Jati garis pemisah antara tiga martabat batin (Ahadiyat, Wahdat, dan Wahidiyat) dengan empat martabat (alam arwah, alam mitsal, alam ajsam, dan alam insan kamil) yang merupakan gambaran wujud yang lahir, tidak dimunculkan. Pemikiran tentang manusia dalam Serat Wirid Hidayat Jati adalah tulisan tasawuf heterodoks yang dipengaruhi ajaran Martabat Tujuh yang bersumber dari kitab tasawuf wahdat al-wujud berjudul Al-Tuhfat alMursalah ila Ruh al-Nabi oleh Muhammad ibn Fadlullah al-Burhanpuri dari India (w. $1620 \mathrm{M}$ ) yang berkembang di Nusantara dan juga masuk di Jawa. Ajaran Martabat Tujuh dari Muhammad ibn Fadlullah al-Burhanpuri berdasarkan atas faham pantheisme-monism Ibn 'Arabi (w.1240 M). Hal ini merupakan salah satu dari yang membedakan dari kitab koreksi Tuhfat alMursalah $(1660 \mathrm{M})$ yang ditulis oleh guru Abdur Rauf as-Sinkili, yaitu Ibrahim ibn Hasan al-Kurani sebagai koreksi tulisan tasawuf heterodoks wahdat al-wujud atas permintaan muridnya, dan koreksi kembali ortodoks ini sebenarnya juga telah ditransmisikan di Jawa melalui Syaikh Abdul Muhyi, Pamijahan, Priangan. Adapun konsep wahdat al-wujud atau manunggaling kawula Gusti adalah inti dari ajaran pokok ajaran dalam Serat Wirid Hidayat Jati. Ungkapan roroning atunggal masih tetap tampak dipertahankan sebagai simbol yang menggambarkan kesatuan manusia dan Tuhan. Manusia dan Tuhan merupakan hal yang berbeda, namun keduanya menjadi satu. Kesatuan Tuhan dan manusia digambarkan sebagai kesatuan antara dzat dan sifatnya, sifat adalah bukan dzat, namun juga bukan selain dzat.

Karakter sinkretis menjadi ciri menonjol dalam keilmuan Islam di Jawa pedalaman terutama setelah era kekuasaan pemerintahan berpusat di Pajang. Di samping juga karena pengaruh ajaran Hindu sebelumnya serta keilmuan yang bersumber dari para pujangga dan para bangsawan keraton Jawa. Serat-serat keraton tersebut sempat memberi warna keilmuan Islam bagi masyarakat Jawa Tengah yang telah lama menerima pengaruh HinduBuddha.

\section{KESIMPULAN}

Para penyebar keilmuan Islam di pesisir utara Jawa Tengah pada abad ke-15 sampai dengan ke-17 telah berhasil memperlihatkan karakter legalistik dan menghindarkan masyarakat dari keilmuan mistisisme yang menyesatkan. Namun kelambanan penyiaran keilmuan Islam di daerah 
pedalaman Jawa Tengah mengakibatkan ketidaksetaraan tingkat pemahaman dan sebagai akibat dari pengaruh ajaran Syaikh Siti Jenar dan pengaruh Hindu yang lama berakar pada masyarakat Jawa. Maka keilmuan Islam di sini berkarakter sinkretisme, berfokus kepada mistisisme heterodoks.Keilmuan ini pada masa berikutnya dikenal sebagai Ilmu Islam Kejawen.[]

\section{Catatan Akhir:}

*Prof. Dr. Ismawati, M.Ag. adalah Dosen Pascasarjana IAIN Walisongo Semarang.

${ }^{1}$ Nusantara adalah nama yang lebih dikenal untuk Indonesia sebelum abad ke- 20. Arti kata Nusantara ini adalah pulau-pulau di antara lautan, karena Nusantara terdiri dari sekitar 13.000 pulau besar dan kecil di antara laut yang sangat luas.

${ }^{2}$ De Graaf and Pigeaud, Kerajaan-kerajaan Islam di Jawa, (Jakarta: Grafiti Pers, 1987), h. 52, 78.

${ }^{3}$ Panitia Penyusun, Sejarah Kota Semarang, (Semarang: Pemda Kota Semarang: 1979), h. 7.

${ }^{4}$ Mas'ud Thoyib, Tafsir Sejarah Sunan Katong, Pencetus Nama Kaliwungu, (Kendal: Sanggar Budaya, 1987), h. 4

${ }^{5}$ Damais, L.C., Epigrafi dan Sejarah Nusantara: Pilihan Karangan Louis Charles Damais, (Jakarta: EFFO, 1995), h. 285

${ }^{6}$ Drewes, New Light on the Coming Islam to Indonesia dalam Ahmad Ibrahim, Readings on Islam in Southeast Asia, Institute of Southeast Asian Studiest, t.t.), hlm. 16.

${ }^{7}$ Tim Penyusun, Ensiklopedi Umum, (Yogyakarta: Yayasan Kanisius, 1973), h. 583 73

${ }^{8}$ Anthony Reid, Sejarah Modern Awal Asia Tenggara, (Jakarta: LP3ES, 2004), h.

${ }^{9}$ Sanusi Pane, Sejarah Indonesia I, cet. ke-4, (Jakarta: Balai Pustaka, 1950), h. 28

${ }^{10}$ Khong Yuanzhi, Muslim Tionghoa Cheng Ho, (Jakarta: Yayasan Obor Indonesia, 2000), h. 100-103.

${ }^{11}$ Yuanzhi, Muslim Tionghoa, h. 105

${ }^{12}$ Robson, S.O., Jawa at the Crossroads: Aspect of Javanese Cultural History in the 14 th and 15 th Centuries in $B K I, 1981$, h.. 277.

${ }^{13}$ Robson, $B K I$, h. 270-271.

${ }^{14}$ Nurcholis Majid, Bilik-bilik Pesantren: Sebuah Potret Perjalanan, (Jakarta: Paramadina, 1997), h. 56

${ }^{15}$ Pigeaud, Th. G. Th., Literature of Java, Descriptive List of Javanese Manuscript, (Leiden: Bibliotica Universiti Leiden, 1967), h. 94. 
${ }^{16}$ Van der Chijs, J.A., "Bidragen tot de Geschie Denys van het Inlandsch-Indie: aan Officiele Bronnen Ontleend", in TBG, XIV, 1864, h. 212-219.

${ }^{17}$ Snouck Hurgronje, "Islam di Hindia Belanda", in Hurgronje, Kumpulan Karangan Snouck Hurgronje X, (Jakarta: INIS,1994), h. 140

${ }^{18}$ Purwadi, Sejarah Sunan Kalijaga, (Yogyakarta: Persada, 2003), h. 173

${ }^{19}$ Denys Lombard, Nusa Jawa: Silang Budaya, Jaringan Asia, II, (Jakarta: PT Gramedia Pustaka Utama, 2000), h. 56.

${ }^{20}$ Richard W., Bulliet, The Patricians of Nishapur, (Cambridge: Harvard University Press, 1972), h. 250.

${ }^{21}$ Agus, Sunyoto, Sejarah Perjuangan Sunan Ampel: Taktik dan Strategi Dakwah Islam di Jawa Abad 14-15, (Surabaya: LPLI Sunan Ampel, 1990), h. 15,

${ }^{22}$ Wahjoetomo, Perguruan Tinggi Pesantren, Pendidikan Alternatif Masa Depan, (Jakarta: Gema Insani Press, 1971), h. 71

${ }^{23}$ Bakri Bahtiar Kholis and Nurul Fitriyah, "Ajaran Putih dari Gunung", Gatra, Edisi Khusus, No. 5, Tahun VII, 2001.

${ }^{24}$ Badri Yatim, Sejarah Sosial Tanah Suci Hijaz (Mekah dan Madinah), 1800-1925 (Jakarta : Logos Wacana Ilmu, 1999), h. 48

${ }^{25}$ De Graaf and Pigeaud, KerajaaN-kerajaan, h. 31.

${ }^{26}$ Bruinessen, Kitab Kuning, h. 88.

${ }^{27}$ Zamahsyari Dhofier, Tradisi Pesantren, Studi Tentang Pandangan Hidup Kiai, (Jakarta: LP3ES, 1994), h. 34.

${ }^{28}$ J. Spencer, Trimingham, The Sufi Orders in Islam, (London: Oxford University, 1988) h.12.

${ }^{29}$ Drewes G.W.J., dalam de Graaf, H.J. dan Th.G.Th. Pigeaud, Kerajaan-kerajaan Islam di Jawa, (Jakarta: Grafiti Pers, 1987), h. 31

${ }^{30}$ Hanun Asrohah, Pelembagaan Pesantren, Asal-usul dan Pelembagaan Pesantren di Jawa, Disertasi, (Jakarta: UIN Syarif Hidayatullah, 2002), h. 90.

${ }^{31}$ Martin, Van Bruinessen, Kitab Kuning, Pesantren dan Tarekat, (Bandung: Penerbit Mizan, 1995), h. 28

${ }^{32}$ Pigeaud, Th. G. Th., Literature of Java, Descriptive List of Javanese Manuscript, (Leiden: Bibliotica Universiti Leiden, 1967), h. 78.

${ }^{33}$ Drewes, G.W.J., An Early Javanese Code of Muslim Ethics, The Hague: Martinus Nijhoff, 1978), h. 7-8.

${ }^{34}$ Drewes, G.W.J., The Admonitions of Seh Bari,(The Hague-Martinus Nijhoff, 1969), h. 114.

${ }^{35}$ Hamam Rochani, Pangeran Juminah dan Kabupaten Kaliwungu, (Semarang: Intermedia Paramadina, 2009), h. 33-34

${ }^{36}$ Karel A.Steenbrink, Mencari Tuhan dengan Kacamata Barat, (Yogyakarta: IAIN Sunan Kalijaga Press, 1988), h. 122.

${ }^{37}$ Yatim, Sejarah, h. 213. 
${ }^{38}$ De Graaf dan Pigeaud, Kerajaan-kerajaan, h. 30.

${ }^{39}$ J. Soegiarto, LOr 6425, 1941.

${ }^{40}$ De Graaf and Pigeaud, Kerajaan- kerajaan , h. 30

${ }^{41}$ Abdul Munir Mulkhan, Ajaran dan Jalan Kematian Syaikh Siti Jenar, (Yogyakarta: Kreasi Wacana, 2003), h. 114

${ }^{42}$ Yatim, Sejarah Sosial, h. 47-48

${ }^{43}$ Pigeaud, Literature of Java, h. 78.

${ }^{44}$ Dhofier, Tradisi, h. 132.

${ }^{45}$ Lombard, Nusa Jawa, h. 73.

${ }^{46}$ Ricklefs, H.C., Sejarah, h. 108

${ }^{47}$ Johan Hendrik Meuleman, Indonesia Islam between Particularity and University, Studi Islamika, Vol. IV, No. 3, 1977), h. 106.

${ }^{48}$ Bruinessen, Kitab Kuning, h. 95

${ }^{49}$ Anthony Reid, Sejarah Modern Awal Asia Tenggara,(Jakarta: LP3ES, 2004), h.8

${ }^{50}$ Bruinessen, Kitab Kuning, h. 209-210.

${ }^{51}$ Niels Mulder, Agama, Hidup Sehari-hari dan Perubahan Budaya Jawa, Muang Thai dan Filipina, (Jakarta: Gramedia Pustaka Utama, 1999), h. 312

${ }^{52}$ Kuntowijoyo, Dinamika Sejarah Umat Islam Indonesia, (Yogyakarta: Salahuddin Press, 1985), h. 44

${ }^{53}$ Nurcholis Madjid, Islam Agama Kemanusiaan: Membangun Tradisi dan Visi Baru Islam Indonesia, (Jakarta: Paramadina, 1999), h. 25

${ }^{54}$ Dawam Raharjo, "Islam Faktual, Antara Tradisi Besar dan Tradisi Kecil”, dalam M. Bambang Pranowo, Islam Faktual, Antara Relasi Kuasa, (Yogyakarta: Adicita Karya Nusa, 1998), h. xiii

${ }^{55}$ Simuh, Mistik Islam Kejawen Raden Ngabehi Ranggawarsita, (Jakarta: UI Press, 1988), h. 22

${ }^{56}$ Hilman Hadikusuma, Antropologi Agama, (Bandung: Citra Aditya Bakti, 1993), h. 66 .

${ }^{57}$ Samidi Khalim, Islam dan Spiritualitas Jawa, (Semarang, RaSAIL Media Group, 2008), h. 66

${ }^{58}$ Purbatjaraka dan Tardjan Hadidjaja, Kepustakaan Jawa, (Jakarta: Jambatan, 1952), h. 103 23-24

${ }^{59}$ Simuh, Mistik Islam Kejawen, (Jakarta: Penerbit Universitas Indonesia, 1988), h.

${ }^{60}$ Snouck Hurgronje, Islam di Hindia Belanda,(Jakarta: Bhratara,1989), h.38,39,40.

${ }^{61}$ Purbatjaraka dan Tardjan Hadidjaja, Kepustakaan Jawa, (Jakarta: Jambatan, 1952), h. 124-125

${ }^{62}$ Th. G.Th. Pigeaud, Literature of Java, Vol. I, (Leiden: The Haque Martinus Nijhoff, 1967), h. 242 


\section{DAFTAR PUSTAKA}

Asrohah, Hanun, Pelembagaan Pesantren, Asal-usul dan Pelembagaan Pesantren di Jawa, Disertasi, (Jakarta: UIN Syarif Hidayatullah, 2002).

Azra, Azyumardi, Perspektif Islam di Asia Tengara, Jakarta: Obor, 1989.

Van Bruinessen, Martin, Kitab Kuning, Pesantren dan Tarekat, (Bandung: Penerbit Mizan, 1995).

Bulliet, Richard W., The Patricians of Nishapur, (Cambridge: Harvard University Press, 1972).

Vander Chijs, J.A., "Bidragen tot de Geschie Denys van het InlandschIndie: aan Officiele Bronnen Ontleend", dalam TBG, XIV, 1864.

Damais, L.C., Epigrafi dan Sejarah Nusantara: Pilihan Karangan Louis Charles Damais, (Jakarta: EFFO, 1995).

Dhofier, Zamakhsyari, Tradisi Pesantren, Studi Tentang Pandangan Hidup Kiai, (Jakarta: LP3ES, 1994).

Djamil, Abdul, "Aspek Islam dalam Sastra Jawa”, dalam Darori Amin, Islam dan Kebudayaan Jawa, (Yogyakarta: Gama Media, 2000).

Drewes, G.W.J., An Early Javanese Code of Muslim Ethics, (The Hague: Martinus Nijhoff, 1978).

Drewes, G.W.J., The Admonitions of Seh Bari, (The Hague- Martinus Nijhoff, 1969).

Drewes, New Light on the Coming Islam to Indonesia dalam Ahmad Ibrahim, Readings on Islam in Southeast Asia, Institute of Southeast Asian Studiest, t.t.

Ensiklopedi Umum, (Yogyakarta: Yayasan Kanisius, 1973).

De Graaf, H.J. dan Th.G.Th. Pigeaud, Kerajaan-kerajaan Islam di Jawa, (Jakarta: Grafiti Pers, 1987).

Hadikusuma, Hilman, Antropologi Agama, (Bandung: Citra Aditya Bakti, 1993).

Hurgronje, Snouck, "Islam di Hindia Belanda", dalam Hurgronje, Kumpulan Karangan Snouck Hurgronje X, (Jakarta: INIS, 1994).

Hurgronje, Snouck, Islam di Hindia Belanda, (Jakarta: Bhratara, 1989). 
Khalim, Samidi, Islam dan Spiritualitas Jawa, (Semarang, RaSAIL Media Group, 2008).

Kholis, Bakri Bahtiar dan Nurul Fitriyah, "Ajaran Putih dari Gunung", Gatra, Edisi Khusus, No. 5, Tahun VII, 2001.

Kuntowijoyo, Dinamika Sejarah Umat Islam Indonesia, (Yogyakarta: Salahuddin Press, 1985).

Lombard, Denys, Nusa Jawa: Silang Budaya, Jaringan Asia, II, (Jakarta: PT Gramedia Pustaka Utama, 2000).

Majid, Nurcholis, Bilik-bilik Pesantren: Sebuah Potret Perjalanan, (Jakarta: Paramadina, 1997).

Madjid, Nurcholis, Islam Agama Kemanusiaan : Membangun Tradisi dan Visi Baru Islam Indonesia, (Jakarta: Paramadina, 1999).

Meuleman, Johan Hendrik, Indonesia Islam between Particularity and University, Studi Islamika, Vol. IV, No. 3, 1977.

Mulder, Niels, Agama, Hidup Sehari-hari dan Perubahan Budaya Jawa, Muang Thai dan Filipina, (Jakarta: Gramedia Pustaka Utama, 1999).

Mulkhan, Abdul Munir, Ajaran dan Jalan Kematian Syaikh Siti Jenar, (Yogyakarta: Kreasi Wacana, 2003).

Pane, Sanusi, Sejarah Indonesia I, cet. Ke-4, (Jakarta: Balai Pustaka, 1950).

Panitia Penyusun Buku Sejarah Kota Semarang, Sejarah Kota Semarang, (Semarang: Pemda Kota Semarang, 1979).

Pigeaud, Th. G. Th., Literature of Java, Descriptive List of Javanese Manuscript, (Leiden: Bibliotica Universiti Leiden, 1967).

Purbatjaraka dan Tardjan Hadidjaja, Kepustakaan Jawa, (Jakarta: Jambatan, 1952)

Purwadi, Sejarah Sunan Kalijaga, (Yogyakarta: Persada, 2003).

Raharjo, M. Dawam, "Islam Faktual, Antara Tradisi Besar dan Tradisi Kecil", dalam M. Bambang Pranowo, Islam Factual, Antara Relasi Kuasa, (Yogyakarta: Adicita Karya Nusa, 1998)

Reid, Anthony, Sejarah Modern Awal Asia Tenggara, (Jakarta: LP3ES, 2004).

Ricklefs, H.C., Sejarah Indonesia Modern, (Yogyakarta, Gajah Mada University Press, 1992).

Robson, S.O., Jawa at the Crossroads: Aspect of Javanese Cultural History in the 14 th and 15 th Centuries dalam BKI, 1981 
Rochani, Hamam, Pangeran Juminah dan Kabupaten Kaliwungu, (Semarang: Intermedia Paramadina, 2009).

Simuh, Mistik Islam Kejawen Raden Mgabehi Ranggawarsita, (Jakarta: UI Press, 1988).

Steenbrink, Karel A., Mencari Tuhan dengan Kacamata Barat, (Yogyakarta: IAIN Sunan Kalijaga Press, 1988).

J. Soegiarto, Suluk Musawaratan, LOr 6425, (Leiden, 1941).

Sunyoto, Agus, Ajaran Tasawuf dan Pembinaan Sikap Hidup Santri Pesantren Nurul Haq Surabaya, Studi Kasus, Tesis, (Malang: IPS IKIP, 1989).

Sunyoto, Agus, Sejarah Perjuangan Sunan Ampel: Taktik dan Strategi Dakwah Islam di Jawa Abad 14-15, (Surabaya: LPLI Sunan Ampel, 1990).

Thoyib, Mas'ud, Tafsir Sejarah Sunan Katong, Pencetus Nama Kaliwungu, (Kendal: Sanggar Budaya, 1987).

Trimingham, J. Spencer, The Sufi Orders in Islam, (London: Oxford University, 1988).

Wahjoetomo, Perguruan Tinggi Pesantren, Pendidikan Alternatif Masa Depan, (Jakarta: Gema Insani Press, 1971).

Yatim, Badri, Sejarah Peradaban Islam, (Jakarta: Raja Grafindo Persada, 1995).

Yatim, Badri, Sejarah Sosial Keagamaan Tanah Suci, Hijaz (Mekah dan Madinah) 1800-1925, (Jakarta: Logos Wacana Ilmu, 1999).

Yuanzhi, Khong, Muslim Tionghoa Cheng Ho, (Jakarta: Yayasan Obor Indonesia, 2000). 